\title{
Polaribacter dokdonensis sp. nov., isolated from seawater
}

Correspondence

Jung-Hoon Yoon

jhyoon@kribb.re.kr
The genus Polaribacter was first proposed by Gosink et al. (1998) with the description of three novel species and reclassification of Flectobacillus glomeratus. At the time of writing, the genus comprises four recognized species: Polaribacter filamentus, $P$. franzmannii, $P$. glomeratus and $P$. irgensii (Gosink et al., 1998). Here we report on the detailed taxonomic characterization of a Polaribacter-like bacterial strain, DSW $-5^{\mathrm{T}}$, which was isolated from seawater.

Seawater collected off Dokdo ( $\left.37^{\circ} 14^{\prime} 12^{\prime \prime} \mathrm{N} 131^{\circ} 52^{\prime} 07^{\prime \prime} \mathrm{E}\right)$, Korea, was used as the source for isolation of bacterial strains. Strain DSW $-5^{\mathrm{T}}$ was isolated by the standard dilution plating technique on marine agar 2216 (MA; Difco) for 7 days at $25^{\circ} \mathrm{C}$. Cell morphology was examined by light microscopy and phase-contrast microscopy (Nikon E600) and transmission electron microscopy. The presence of flagella was determined by transmission electron microscopy using cells from exponentially growing cultures. Gliding motility was investigated as described by Bowman (2000). The Gram-reaction was determined by using the bioMérieux Gram stain kit according to the manufacturer's instructions. The $\mathrm{pH}$ range for growth was determined in marine broth 2216 (MB; Difco) that was adjusted prior to sterilization to various $\mathrm{pH}$ values $(\mathrm{pH} 4 \cdot 5-10 \cdot 5$ at intervals of $0.5 \mathrm{pH}$ units) by the addition of $\mathrm{HCl}$ or $\mathrm{Na}_{2} \mathrm{CO}_{3}$. Growth in the absence of $\mathrm{NaCl}$ was investigated in trypticase soy broth prepared according to the formula of the Difco medium except that no $\mathrm{NaCl}$ was used. Growth at various $\mathrm{NaCl}$

The GenBank/EMBL/DDBJ accession number for the 16S rRNA gene sequence of strain DSW- $5^{\top}$ is DQ004686. concentrations $[0 \cdot 5 \%(\mathrm{w} / \mathrm{v})$ and $1 \cdot 0-10 \cdot 0 \%(\mathrm{w} / \mathrm{v})$ at intervals of $1.0 \%$ ] was investigated in $\mathrm{MB}$ or trypticase soy broth (Difco) at $25^{\circ} \mathrm{C}$. Growth at various temperatures $\left(4-40{ }^{\circ} \mathrm{C}\right)$ was measured on MA. Growth under anaerobic conditions was determined after incubation at $25^{\circ} \mathrm{C}$ in an anaerobic chamber on MA and on MA supplemented with nitrate, both of which had been prepared anaerobically using nitrogen. The ability to grow on various solid media was tested at $25^{\circ} \mathrm{C}$ in nutrient agar (NA; Difco), NA plus $2.5 \%(\mathrm{w} / \mathrm{v}) \mathrm{NaCl}$, trypticase soy agar (TSA; Difco), TSA plus $3 \%(\mathrm{w} / \mathrm{v})$ D-glucose, TSA plus $3 \%(\mathrm{w} / \mathrm{v})$ sucrose, TSA plus $2 \cdot 5 \%(\mathrm{w} / \mathrm{v}) \mathrm{NaCl}$, Levine EMB agar (Difco), MacConkey agar (Difco) and Mueller-Hinton agar (Difco). Catalase and oxidase activities and hydrolysis of casein and starch were determined as described by Cowan \& Steel (1965). Hydrolysis of Tweens 20, 40, 60 and 80 was determined as described by Cowan \& Steel (1965) with a modification that artificial seawater (ASW) was used instead of distilled water. Hydrolysis of aesculin, gelatin and urea and nitrate reduction were determined as described by Lanyi (1987) with a modification that ASW was used instead of distilled water. ASW contained (per litre of distilled water) $23.6 \mathrm{~g} \mathrm{NaCl}, 0.64 \mathrm{~g}$ $\mathrm{KCl}, 4 \cdot 53 \mathrm{~g} \mathrm{MgCl}_{2} \cdot 6 \mathrm{H}_{2} \mathrm{O}, 5 \cdot 94 \mathrm{~g} \mathrm{MgSO}_{4} .7 \mathrm{H}_{2} \mathrm{O}$ and $1.3 \mathrm{~g}$ $\mathrm{CaCl}_{2} \cdot 2 \mathrm{H}_{2} \mathrm{O}$ (Bruns et al., 2001). Hydrolysis of hypoxanthine, tyrosine and xanthine was investigated on MA with the substrate concentrations given by Cowan \& Steel (1965). Hydrolysis of carboxymethylcellulose was tested as described by Bowman (2000) using MA as the basal medium. Hydrolysis of chitin (Sigma) was determined on solid and in liquid marine salts basal media (Baumann \& Baumann, 1981) containing $0 \cdot 5 \%(\mathrm{w} / \mathrm{v})$ chitin as the sole carbon source. The 
presence of flexirubin-type pigments was investigated as described by Reichenbach (1992). $\mathrm{H}_{2} \mathrm{~S}$ production was tested according to the method of Bruns et al. (2001). Acid production from carbohydrates was determined as described by Leifson (1963). Growth on several substrates was tested in a basal medium containing $0.2 \mathrm{~g} \mathrm{NaNO}_{3}, 0.2 \mathrm{~g} \mathrm{NH}_{4} \mathrm{Cl}$ and 0.05 g yeast extract in $1000 \mathrm{ml}$ ASW (Bruns et al., 2001) as described by Suzuki et al. (2001). Enzyme activity was determined by using the API ZYM system (bioMérieux). Susceptibility to antibiotics was tested on MA plates using discs containing the following antibiotics: polymyxin B (100 U), streptomycin (50 $\mu \mathrm{g})$, penicillin $\mathrm{G}(20 \mathrm{U})$, chloramphenicol $(100 \mu \mathrm{g})$, ampicillin $(10 \mu \mathrm{g})$, cephalothin $(30 \mu \mathrm{g})$, gentamicin $(30 \mu \mathrm{g})$, novobiocin $(5 \mu \mathrm{g})$, tetracycline $(30 \mu \mathrm{g})$, kanamycin $(30 \mu \mathrm{g})$, lincomycin $(15 \mu \mathrm{g})$, oleandomycin $(15 \mu \mathrm{g})$, neomycin $(30 \mu \mathrm{g})$ or carbenicillin $(100 \mu \mathrm{g})$. Other physiological and biochemical tests were performed with the API 20E system (bioMérieux).

Cell biomass of strain DSW $-5^{\mathrm{T}}$ for DNA extraction and for isoprenoid quinone analysis was obtained by cultivation for 2 days in $\mathrm{MB}$ at $25^{\circ} \mathrm{C}$. Chromosomal DNA was isolated and purified according to the method described previously (Yoon et al., 1996), with the exception that RNase T1 was used in combination with RNase A to minimize contamination with RNA. The 16S rRNA gene was amplified by PCR using two universal primers as described previously (Yoon et al., 1998). Sequencing of the amplified 16S rRNA gene and phylogenetic analysis were performed as described by Yoon et al. (2003). Isoprenoid quinones were extracted according to the method of Komagata \& Suzuki (1987) and analysed by using reversed-phase HPLC and a YMC ODS-A $(250 \times 4 \cdot 6 \mathrm{~mm})$ column. Polar lipids were extracted according to the procedures described by Minnikin et al. (1984) and identified by two-dimensional TLC followed by spraying with appropriate detection reagents (Minnikin et al., 1984; Komagata \& Suzuki, 1987). For fatty acid methyl ester analysis, cell mass of strain DSW $-5^{\mathrm{T}}$ was harvested from agar plates after incubation for 3 days on MA at $25^{\circ} \mathrm{C}$. Fatty acid methyl esters were extracted and prepared according to the standard protocol of the MIDI/Hewlett Packard Microbial Identification System (Sasser, 1990). The DNA G + C content was determined by the method of Tamaoka \& Komagata (1984) with a modification that DNA was hydrolysed and the resultant nucleotides were analysed by reversed-phase HPLC.

Morphological, cultural, physiological and biochemical characteristics of strain DSW $-5^{\mathrm{T}}$ are given in the species description or are shown in Table 1, together with those of the four recognized Polaribacter species. The almost complete $16 \mathrm{~S}$ rRNA gene sequence of strain DSW $-5^{\mathrm{T}}$, comprising $1475 \mathrm{nt}$ (approximately $96 \%$ of the Escherichia coli $16 \mathrm{~S}$ rRNA gene sequence), was determined. Comparative $16 \mathrm{~S}$ rRNA gene sequence analyses revealed that strain DSW $-5^{\mathrm{T}}$ was phylogenetically affiliated to the genus Polaribacter of the family Flavobacteriaceae (Fig. 1). In the neighbourjoining tree based on 16S rRNA gene sequences, strain
DSW $-5^{\mathrm{T}}$ joined the cluster comprising Polaribacter species with a bootstrap confidence level of $100 \%$, and the relationship between this clade and the cluster comprising Tenacibaculum species was supported by a bootstrap resampling value of $100 \%$ (Fig. 1). Similar topologies were found in trees generated with the maximum-likelihood and maximumparsimony algorithms (Fig. 1). The $16 \mathrm{~S} \mathrm{rRNA}$ gene sequence of strain DSW $-5^{\mathrm{T}}$ exhibited similarity values of $96 \cdot 2-96 \cdot 8 \%$ to those of the type strains of the four recognized Polaribacter species, $93 \cdot 1-95 \cdot 1 \%$ to Tenacibaculum species and $<90 \cdot 2 \%$ to other species used in the phylogenetic analysis (Fig. 1).

Strain DSW $-5^{\mathrm{T}}$ contained menaquinone-6 (MK-6), at a peak area ratio of approximately $96 \%$, as the predominant isoprenoid quinone. Strain DSW $-5^{\mathrm{T}}$ contained large amounts of branched, hydroxy, straight-chain and unsaturated fatty acids; the major components ( $>1 \%$ of the total fatty acids) were iso- $\mathrm{C}_{15: 0}(17 \cdot 2 \%)$, iso- $\mathrm{C}_{15: 1}(15 \cdot 4 \%)$, iso- $\mathrm{C}_{15: 0} 3-\mathrm{OH}$ $(14 \cdot 3 \%)$, iso- $\mathrm{C}_{17: 0} 3-\mathrm{OH}(8 \cdot 4 \%), \mathrm{C}_{16: 1} \omega 7 c$ and/or iso$\mathrm{C}_{15: 0} 2-\mathrm{OH}(6 \cdot 6 \%), \mathrm{C}_{15: 1} \omega 6 c(5 \cdot 1 \%)$, iso- $\mathrm{C}_{16: 0} 3-\mathrm{OH}$ $(5 \cdot 0 \%)$, iso- $\mathrm{C}_{13: 0}(4 \cdot 9 \%), \mathrm{C}_{15: 0} 3-\mathrm{OH}(3 \cdot 7 \%), \mathrm{C}_{18: 0}$ $(3 \cdot 2 \%), \mathrm{C}_{15: 0}(2 \cdot 3 \%), \mathrm{C}_{16: 0}(1 \cdot 7 \%)$, iso- $\mathrm{C}_{16: 1}(1 \cdot 3 \%)$, $\mathrm{C}_{17: 1} \omega 6 c(1 \cdot 3 \%), \mathrm{C}_{16: 0} 3-\mathrm{OH}(1 \cdot 3 \%)$, iso- $\mathrm{C}_{14: 0}(1 \cdot 1 \%)$ and $\mathrm{C}_{16: 0} 2-\mathrm{OH}(1 \cdot 0 \%)$. This fatty acid profile was similar to those of Polaribacter species analysed previously, although there were differences in the proportions of some fatty acids, perhaps because of differences in cultivation conditions, e.g. temperatures and cultivation media (Gosink et al., 1998). The phospholipid identified in strain DSW $-5^{\mathrm{T}}$ was phosphatidylethanolamine, and other major polar lipids were three unidentified phospholipids and an amino-group-containing lipid that was ninhydrin-positive. The DNA G + C content of strain DSW $-5^{\mathrm{T}}$ was $30 \cdot 0 \mathrm{~mol} \%$. These chemotaxonomic properties were in agreement with the result of monothetic phylogenetic classification of strain DSW $-5^{\mathrm{T}}$ as a member of the genus Polaribacter (Gosink et al., 1998). Strain DSW $-5^{\mathrm{T}}$ was distinguishable from recognized Polaribacter species based on differences in some phenotypic characteristics (Table 1). The $16 \mathrm{~S}$ rRNA gene sequence similarity data were sufficient to classify strain DSW $-5^{\mathrm{T}}$ in a species that is separate from all recognized Polaribacter species (Stackebrandt \& Goebel, 1994). Therefore, on the basis of the data presented, strain DSW $-5^{\mathrm{T}}$ should be placed in the genus Polaribacter as the type strain of a novel species, for which the name Polaribacter dokdonensis sp. nov. is proposed.

\section{Description of Polaribacter dokdonensis sp. nov.}

Polaribacter dokdonensis (dok.do.nen'sis. N.L. masc. adj. dokdonensis of Dokdo, an island of Korea, from where the type strain was isolated).

Cells are Gram-negative, non-spore-forming, non-motile, aerobic rods $(0 \cdot 4-0 \cdot 6 \times 0 \cdot 8-5 \cdot 0 \mu \mathrm{m})$; coccoid cells are often observed. Colonies on MA are circular, smooth, glistening, convex, orange-coloured and $0 \cdot 8-1 \cdot 2 \mathrm{~mm}$ in diameter after incubation for 3 days at $25^{\circ} \mathrm{C}$. Optimal growth occurs at $25-28^{\circ} \mathrm{C}$; growth occurs at 4 and $33^{\circ} \mathrm{C}$, but not at $34^{\circ} \mathrm{C}$. Optimal $\mathrm{pH}$ for growth is $7 \cdot 0-8 \cdot 0$; growth occurs at $\mathrm{pH} 5 \cdot 5$, 


\section{Table 1. Differential phenotypic characteristics of Polaribacter species}

Species: 1, P. dokdonensis sp. nov.; 2, P. filamentus; 3, P. franzmannii; 4, P. glomeratus; 5, P. irgensii. Data for reference species were taken from Gosink et al. (1998). +, Positive; -, negative; W, weakly positive; ND, not determined. All species were positive for growth at $4{ }^{\circ} \mathrm{C}$ and on marine agar 2216. All species were negative for Gram-staining, urease, motility, production of flexirubin-type pigments, hydrolysis of chitin and cellulose, indole production, the Voges-Proskauer reaction, growth on NA, TSA plus $3 \%$ (w/v) D-glucose, TSA plus $2 \cdot 5 \%$ (w/v) NaCl, EMB agar, MacConkey agar and Mueller-Hinton agar and utilization of D-ribose, DL-aspartate, L-leucine, L-proline, ethanol, methanol, acetate, benzoate, citrate, pyruvate and succinate.

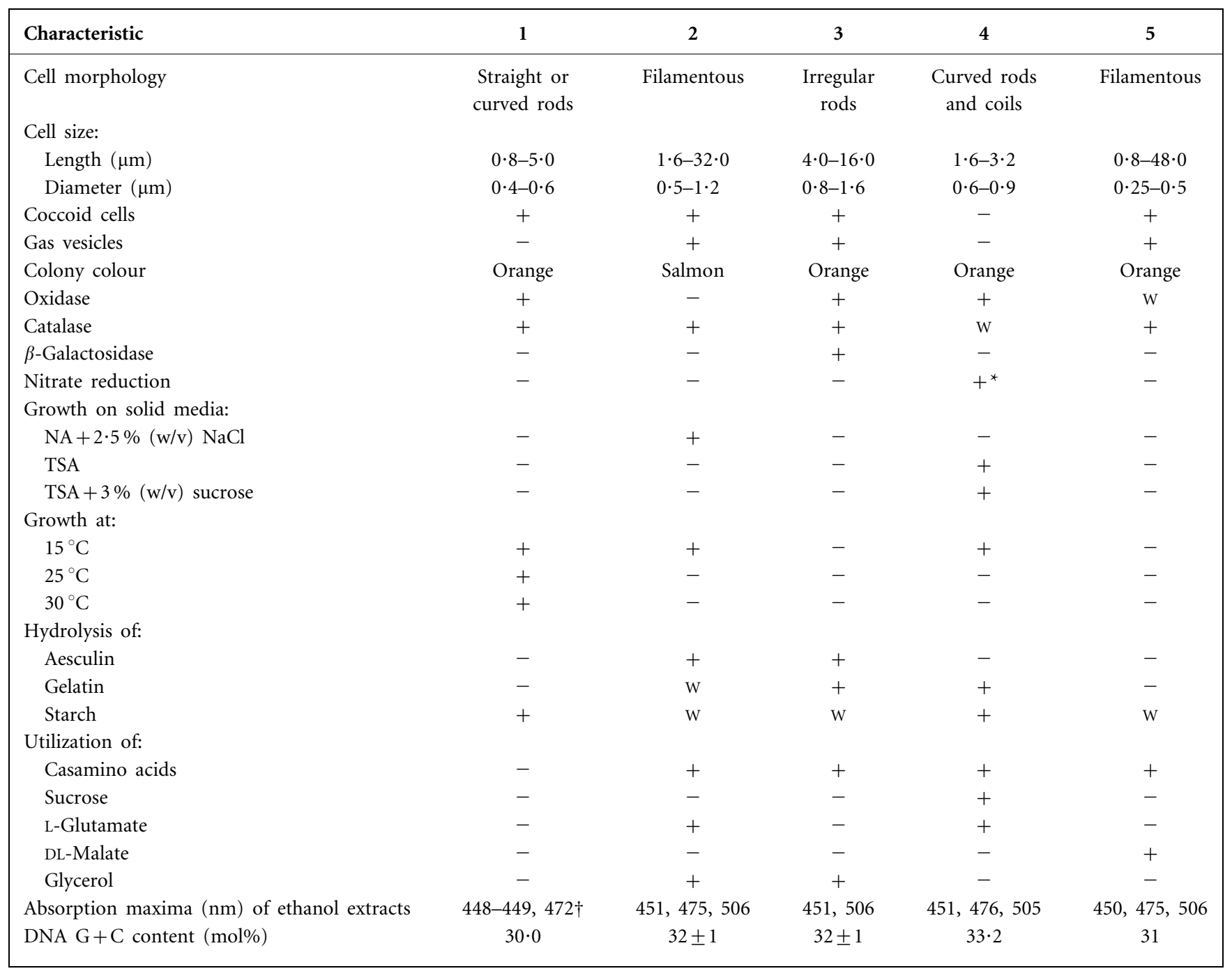

${ }^{\star}$ Reported as negative by McGuire et al. (1987).

$\dagger$ An identical result for $P$. dokdonensis was obtained from acetone/methanol extracts.

but not at $\mathrm{pH} 5 \cdot 0$. Optimal growth occurs in the presence of $2 \%(\mathrm{w} / \mathrm{v}) \mathrm{NaCl}$; growth does not occur in the absence of $\mathrm{NaCl}$ or in the presence of $>6 \%(\mathrm{w} / \mathrm{v}) \mathrm{NaCl}$. Growth does not occur under anaerobic conditions on MA or on MA supplemented with nitrate. Tweens 20, 40, 60 and 80 are hydrolysed, but casein, hypoxanthine, xanthine and L-tyrosine are not. $\mathrm{H}_{2} \mathrm{~S}$ is not produced. Arginine dihydrolase, lysine decarboxylase, ornithine decarboxylase and tryptophan deaminase are absent. In assays with the API ZYM system, alkaline phosphatase, esterase lipase (C8), leucine arylamidase, valine arylamidase, trypsin, acid phosphatase, naphthol-AS-BI-phosphohydrolase and $N$-acetyl- $\beta$-glucosaminidase are present, esterase (C4) and cystine arylamidase are weakly present, and lipase (C14), $\alpha$-chymotrypsin, $\alpha$-galactosidase, $\beta$-glucuronidase, $\alpha$-glucosidase, $\beta$-glucosidase, $\alpha$-mannosidase and $\alpha$-fucosidase are absent. Peptone and tryptone are utilized as sole carbon and nitrogen sources; D-glucose, D-galactose, D-fructose, D-cellobiose and D-trehalose are not utilized as sole carbon sources. Acid is produced from D-fructose and D-raffinose, but not from 


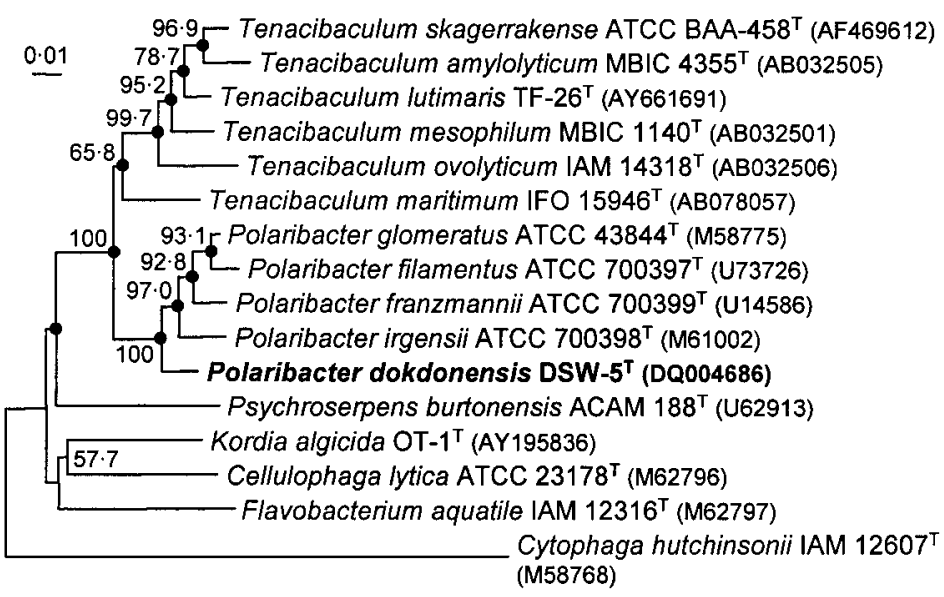

Fig. 1. Neighbour-joining tree based on 16S rRNA gene sequences showing the phylogenetic positions of strain $\mathrm{DSW}-5^{\top}$, Polaribacter species and representatives of some other related taxa. Bootstrap values (expressed as percentages of 1000 replications) $>50 \%$ are shown at the branch points. Cytophaga hutchinsonii IAM $12607^{\top}$ was used as an outgroup. Dots indicate that the corresponding nodes were also recovered in the trees generated with the maximumlikelihood and maximum-parsimony algorithms. Bar, 0.01 substitutions per nucleotide position.

L-arabinose, D-cellobiose, D-galactose, D-glucose, lactose, maltose, D-mannose, D-melezitose, melibiose, L-rhamnose, D-ribose, sucrose, D-trehalose, D-xylose, myo-inositol, D-mannitol or D-sorbitol. Susceptible to penicillin G, chloramphenicol, ampicillin, cephalothin, novobiocin, tetracycline, lincomycin, oleandomycin and carbenicillin, but not to polymyxin B, streptomycin, gentamicin, kanamycin or neomycin. The predominant menaquinone is MK- 6 . The major fatty acids ( $>10 \%$ of the total fatty acids) are iso$\mathrm{C}_{15: 0}(17 \cdot 2 \%)$, iso- $\mathrm{C}_{15: 1}(15 \cdot 4 \%)$ and iso- $\mathrm{C}_{15: 0} 3-\mathrm{OH}$ $(14 \cdot 3 \%)$. The major polar lipids are phosphatidylethanolamine, three unidentified phospholipids and an aminogroup-containing lipid. The DNA G+C content is $30 \cdot 0$ mol\% (HPLC). Other phenotypic properties are given in Table 1.

The type strain, DSW $-5^{\mathrm{T}}\left(=\mathrm{KCTC} 12392^{\mathrm{T}}=\mathrm{DSM} 17204^{\mathrm{T}}\right)$, was isolated from seawater off Dokdo in the East Sea of Korea (also known as the Sea of Japan).

\section{Acknowledgements}

This work was supported by the 21C Frontier program of Microbial Genomics and Applications (grant MG05-0401-2-0) from the Ministry of Science and Technology (MOST) of the Republic of Korea. We are grateful to the Ulleung County Administration and the Cultural Heritage Administration of the Republic of Korea for aiding access to Dokdo, Korea.

\section{References}

Baumann, P. \& Baumann, L. (1981). The marine gram-negative eubacteria: genera Photobacterium, Beneckea, Alteromonas, Pseudomonas and Alcaligenes. In The Prokaryotes, vol. 2, pp. 1302-1331. Edited by M. P. Starr, H. Stolp, H. G. Trüper, A. Balows \& H. Schlegel. Berlin: Springer.

Bowman, J. P. (2000). Description of Cellulophaga algicola sp. nov., isolated from the surfaces of Antarctic algae, and reclassification of Cytophaga uliginosa (ZoBell and Upham 1944) Reichenbach 1989 as Cellulophaga uliginosa comb. nov. Int J Syst Evol Microbiol 50, 1861-1868.
Bruns, A., Rohde, M. \& Berthe-Corti, L. (2001). Muricauda ruestringensis gen. nov., sp. nov., a facultatively anaerobic, appendaged bacterium from German North Sea intertidal sediment. Int J Syst Evol Microbiol 51, 1997-2006.

Cowan, S. T. \& Steel, K. J. (1965). Manual for the Identification of Medical Bacteria. London: Cambridge University Press.

Gosink, J. J., Woese, C. R. \& Staley, J. T. (1998). Polaribacter gen. nov., with three new species, $P$. irgensii sp. nov., $P$. franzmannii sp. nov. and $P$. filamentus sp. nov., gas vacuolated polar marine bacteria of the Cytophaga-Flavobacterium-Bacteroides group and reclassification of 'Flectobacillus glomeratus' as Polaribacter glomeratus comb. nov. Int J Syst Bacteriol 48, 223-235.

Komagata, K. \& Suzuki, K. (1987). Lipids and cell-wall analysis in bacterial systematics. Methods Microbiol 19, 161-203.

Lanyi, B. (1987). Classical and rapid identification methods for medically important bacteria. Methods Microbiol 19, 1-67.

Leifson, E. (1963). Determination of carbohydrate metabolism of marine bacteria. J Bacteriol 85, 1183-1184.

McGuire, A. J., Franzmann, P. D. \& McMeekin, T. A. (1987). Flectobacillus glomeratus sp. nov., a curved, nonmotile, pigmented bacterium isolated from antarctic marine environment. Syst Appl Microbiol 9, 265-272.

Minnikin, D. E., O'Donnell, A. G., Goodfellow, M., Alderson, G., Athalye, M., Schaal, A. \& Parlett, J. H. (1984). An integrated procedure for the extraction of bacterial isoprenoid quinones and polar lipids. J Microbiol Methods 2, 233-241.

Reichenbach, H. (1992). The order Cytophagales. In The Prokaryotes. A Handbook on the Biology of Bacteria: Ecophysiology, Isolation, Identification, Applications, 2nd edn, pp. 3631-3675. Edited by A. Balows, H. G. Trüper, M. Dworkin, W. Harder \& K. H. Schleifer. New York: Springer.

Sasser, M. (1990). Identification of bacteria by gas chromatography of cellular fatty acids. Technical Note no. 101. Newark, DE: MIDI Inc.

Stackebrandt, E. \& Goebel, B. M. (1994). Taxonomic note: a place for DNA-DNA reassociation and 16S rRNA sequence analysis in the present species definition in bacteriology. Int $J$ Syst Bacteriol 44, 846-849.

Suzuki, M., Nakagawa, Y., Harayama, S. \& Yamamoto, S. (2001). Phylogenetic analysis and taxonomic study of marine Cytophaga-like bacteria: proposal for Tenacibaculum gen. nov. with Tenacibaculum maritimum comb. nov. and Tenacibaculum ovolyticum comb. nov., and description of Tenacibaculum mesophilum sp. nov. and Tenacibaculum amylolyticum sp. nov. Int J Syst Evol Microbiol 51, 1639-1652. 
Tamaoka, J. \& Komagata, K. (1984). Determination of DNA base composition by reverse-phase high-performance liquid chromatography. FEMS Microbiol Lett 25, 125-128.

Yoon, J.-H., Kim, H., Kim, S.-B., Kim, H.-J., Kim, W. Y., Lee, S. T., Goodfellow, M. \& Park, Y.-H. (1996). Identification of Saccharomonospora strains by the use of genomic DNA fragments and rRNA gene probes. Int J Syst Bacteriol 46, 502-505.
Yoon, J.-H., Lee, S. T. \& Park, Y.-H. (1998). Inter- and intraspecific phylogenetic analysis of the genus Nocardioides and related taxa based on 16S rRNA gene sequences. Int J Syst Bacteriol 48, 187-194.

Yoon, J.-H., Kang, K. H. \& Park, Y.-H. (2003). Psychrobacter jeotgali sp. nov., isolated from jeotgal, a traditional Korean fermented seafood. Int J Syst Evol Microbiol 53, 449-454. 